\title{
Heat of Reaction of Diborane with Water and the Heat of Formation of Boric Oxide
}

\author{
Edward J. Prosen, Walter H. Johnson, and Florence Y. Pergiel
}

\begin{abstract}
The heat of reaction of gase us diborane with water to form gaseous hydrogen and a solution of boric acid $\left(\mathrm{H}_{3} \mathrm{BO}_{3}+1,00 \mathrm{H}_{2} \mathrm{O}\right)$ has been measured by passing gaseous diborane through two successive bubblers in a calorimeter. The heat of the reaction obtained was:

$$
\Delta \mathrm{H}_{298.15}=-466.34 \pm 2.26 \mathrm{kj} / \text { mole }(-111.46 \pm 0.54 \mathrm{kcal} / \mathrm{mole}) .
$$
\end{abstract}

Combination of this value with values previously reported for the heat of decomposition of diborane and the heat of solution of boric oxide yields the following value for the heat of formation of crystalline boric oxide from amorphous boron and gaseous oxygen:

$\Delta \mathrm{Hf}_{298.15}=-1280.89 \pm 3.14 \mathrm{kj} /$ mole $(-306.14 \pm 0.75 \mathrm{kcal} / \mathrm{mole})$.

\section{Introduction}

The determination of the heat of formation of boric oxide glass by the combustion of boron in oxygen has led to values which range from -279.9 to $-368 \mathrm{kcal} / \mathrm{mole}$. Roth and Börger $[1,2]^{1}$ obtained a value of $-340 \pm 3 \mathrm{kcal} /$ mole from the combustion of boron in an oxygen bomb with paraffin oil as an auxiliary substance to aid the reaction. Robertson [3] obtained a value of $-368 \pm 17 \mathrm{kcal} / \mathrm{mole}$ from the combustion of boron in an oxygen bomb using no auxiliary substance other than a cotton string fuse. Todd and Miller [4] obtained a value of $-338.4 \pm 0.8 \mathrm{kcal} /$ mole from the combustion of boron in an oxygen bomb with benzoic acid as an auxiliary substance. Eggersgluess, Monroe, and Parker [5] obtained a value of $-281.1 \pm 3.1 \mathrm{kcal} /$ mole from the combustion of boron in an oxygen bomb with paraffin oil and lamp black as auxiliary substances. In all of these determinations, complete combustion of the boron was not achieved and the amount of reaction was determined from a titration of the boric acid formed by dissolving the soluble products of combustion in water. Nathan [6] obtained a value of $-306 \pm 3 \mathrm{kcal} /$ mole from the combustion in an oxygen bomb using iron wire as an auxiliary substance. In this case complete combustion of the boron was achieved although the over-all uncertainty was rather high. Bichowsky and Rossini [7] calculated a value of $-279.9 \mathrm{kcal} /$ mole for the heat of formation of boric oxide glass from the data existing in the literature prior to 1934.

An investigation of the combustion of powdered amorphous boron (obtained from experiments on the decomposition of diborane) in an oxygen bomb has been made. It was found possible to ignite the boron with a fuse of iron wire, but complete combustion of the boron was not obtained. The addition of relatively large quantities of benzoic acid did not effect the complete combustion of the boron.

Figures in brackets indicate the literature references at the end of this paper.
It has been shown that neither the titration of the solution formed by dissolving in water the boric oxide formed in the combustion, nor the difference in weight of the boron placed in the bomb and the residue remaining after combustion, gives a true measure of the amount of reaction. Large amounts of boron oxide remain in the residue even after washing with warm water or digesting with hydrochloric acid. This has been verified by passing chlorine over the residue in a hot quartz tube, according to the method of Winslow and Liebhafsky [8]. In such an experiment with pure boron, all the boron was carried away as boron trichloride. After similar treatment of the residues from the bomb combustion there remained large amounts of a white or gray material.

A method free from many of the difficulties encountered in the combustion of boron is the measurement of the heat of hydrolysis of diborane according to reaction (1), since the heat of formation of diborane and the heat of solution of boric oxide are known.

$\mathrm{B}_{2} \mathrm{H}_{6 \text { (gas) }}+6 \mathrm{H}_{2} \mathrm{O}_{(\text {liq })}+\mathrm{aq}=2 \mathrm{H}_{3} \mathrm{BO}_{3 \text { (aq) }}+6 \mathrm{H}_{2 \text { (gas) }}$.

Roth, Börger, and Bertram [9] measured the heat of hydrolysis by breaking ampoules filled with gaseous diborane under water in a bomb. They obtained a value of $-108 \mathrm{kcal} /$ mole for the resction going to $\left[\mathrm{H}_{3} \mathrm{BO}_{3}+1,000 \mathrm{H}_{2} \mathrm{O}\right]$. However, owing to the uncertainties in the analyses and in obtaining complete reaction under these conditions, their value is probably in error by several kilocalories.

\section{Materials}

The diborane used in this investigation was supplied by the Naval Research Laboratory through the courtesy of R. R. Miller. A sample supplied to the Ohio State University was found by the cryoscopic method to have a purity of 99.95 mole percent $[10]$. 


\section{Apparatus}

\subsection{Calorimetric System}

A submarine-type calorimeter, built by the Precision Scientific Company, was used for these experiments. It consists of a nickel-plated copper calorimeter "can" having a volume of 5 liters, fitted with a stirrer and lid and supported within a Monel calorimeter "well" by three plastic pegs so that there is a $1 / 2$-in. air space between the can and well at all points. The well is fitted with a rubber gasket and a nickel-plated brass cover held in place by six clamp-screws. The thermometer, calorimeter stirrer, heater leads, and connections to the calorimetric reaction vessel pass through tubes attached to the well cover; these tubes prevent water from entering the well when the assembly is lowered into the water bath.

The container for the water bath is made of Monel and has double walls separated by 1 in. of cork insulation; it has a volume of 46.5 liters. Two synchronous motors are provided; one operating at $1,700 \mathrm{rpm}$ is used for circulating the water in the bath, the other, operating at $300 \mathrm{rpm}$, is used for stirring the water in the calorimeter. Ice water circulated through a coil in the bath provides a slight excess of refrigeration; a $100-\mathrm{w}$ heating coil is provided for temperature control. The general characteristics of this type of calorimeter have been described in detail by Dickinson [11].

A servomechanism arranged as an on-off controller was used to maintain the water bath at a constant temperature. The sensing element consisted of a 28ohm platinum resistance thermometer which formed one arm of a Wheatstone bridge circuit; the other arms consisted of two 500-ohm and one 29-ohm coils of manganin. A variable resistor placed in parallel with the 29-ohm coil was used to select the desired temperature to be maintained.

The glass reaction vessel used in these experiments is shown in figure 1 . It consisted of a two-stage bubbler and a helical coil in which the exit gases were cooled to the calorimeter temperature. The large bubbler contained $275 \mathrm{ml}$ of water and the small bubbler contained $100 \mathrm{ml}$ of water. Each bubbler was fitted with a porous corundum frit to produce very small bubbles. The connection between the bubblers was fitted with a vent by which the pressures within the vessels could be equalized at the end of the experiment.

The calorimeter heater consisted of a manganin coil, having a resistance of $121 \mathrm{ohms}$, wound noninductively between two thin-walled concentric copper cylinders and insulated from the cylinders by means of mica sheets. The cylinders were approximately $1 \frac{1}{2}$ in. in diameter and $5 \mathrm{in}$. in length. The inner cylinder was offset at the ends to form a close fit with the outer cylinder; after introducing the heating coil, the ends were sealed by soldering the cylinders together. The heater was nickel plated to avoid corrosion by the water. The heater leads

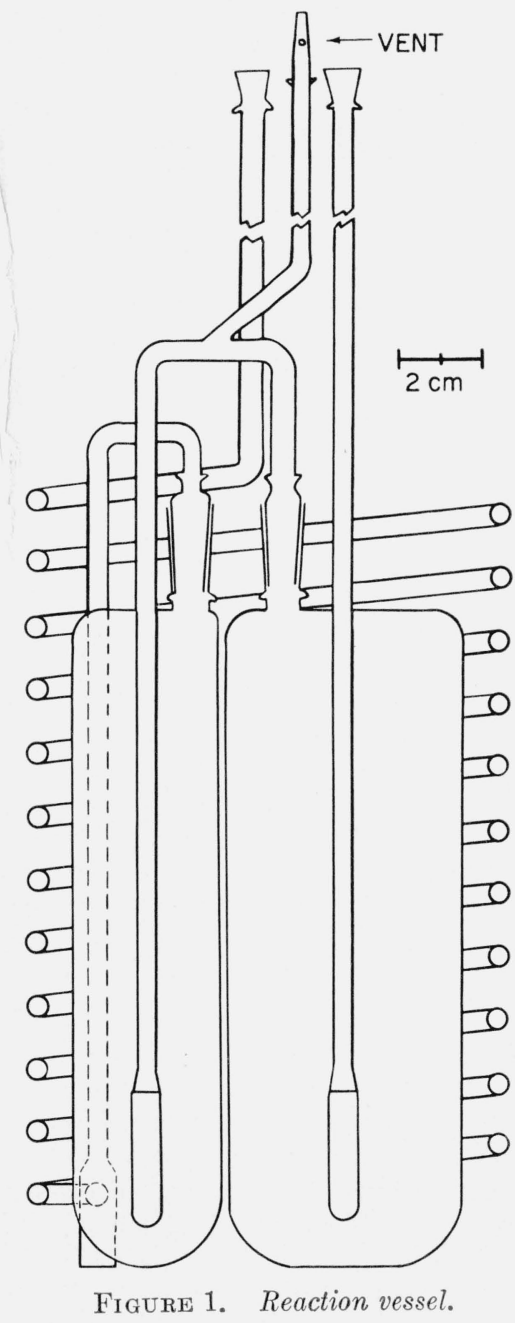

passed through a copper tube soldered to the outer cylinder; the heater was suspended from the calorimeter lid by means of a flange soldered to the end of this tube.

\subsection{Thermometric System}

A calorimetric-type platinum resistance thermometer was used for these experiments, the resistance of this thermometer was 25.546 ohms at $0^{\circ} \mathrm{C}$. Thermometer resistances were measured using a G-2 Mueller bridge in conjunction with a high-sensitivity galvanometer. Readings on the galvanometer scale were made to the nearest 0.5 $\mathrm{mm}$ which corresponded to 50 microdegrees C.

\subsection{Apparatus for Measurement of Electrical Energy}

The electrical energy used for the calibration experiments was obtained from a $120-v$ storage battery from which no other current was drawn 
during the progress of these experiments. The quantity of electrical energy was determined from measurements of the current through the calorimeter heater, the potential drop across the heater, and the time during which the current flowed. The potential drop across the heater was determined from the potential drop across a 10-ohm standard resistor, which was connected in sèries with a 10,000-ohm. standard resistor, both in parallel with the calorimeter heater. The total current was determined from the potential drop across a 0.1 -ohm standard resistor, placed in series with the calorimeter heater. Correction for the quantity of current flowing through the parallel circuit gave the actual current flowing through the calorimeter heater. The potential measurements were determined using a Wenner potentiometer, balanced against a thermostated Weston standard cell. The potentiometer ratio was determined [12] at the time of each experiment in a manner previously described [13]. The resistance thermometer, bridge, potentiometer, standard resistors, and the standard cell were all calibrated in terms of standards maintained at the Bureau.

An automatic solenoid switch [14], actuated by an impulse from the standard seconds signals produced at the Bureau, served to switch the current from an external resistor into the calorimeter heater at the start of the heating period and to interrupt the current at the close of the heating period. The over-all error in timing by this procedure did not exceed $0.01 \mathrm{sec}$

The electrical energy was computed as the product of the current through the heater, the potential drop across the heater and the time during which the current passed through the heater.

\section{Procedure}

The bubblers were filled with 275 and $100 \mathrm{~g}$ of water, and the hydrolysis vessel was assembled. The calorimeter can containing 4,687.63 $\mathrm{g}$ of water was placed in the calorimeter well after which the hydrolysis vessel and calorimeter heater were introduced and the can cover attached. The well cover was then secured, the assembly was lowered into the water bath, the calorimeter stirrer connected, and the platinum thermometer inserted. The inlet and exit tubes of the vessel were then connected to the gas train and air was removed by flushing with helium.

The cylinder containing the diborane was cooled in liquid nitrogen and the diborane degassed to remove any hydrogen which may have been present as a decomposition product. The liquid nitrogen was then replaced by "dry ice" to maintain the diborane at approximately $-80^{\circ} \mathrm{C}$; at this temperature the vapor pressure of diborane is approximately 2 atm.

The jacket (or water bath) was warmed to $27.00^{\circ}$ $\mathrm{C}$ and the jacket control adjusted to maintain this temperature within $\pm 0.001^{\circ} \mathrm{C}$. The temperature of the water in the calorimeter was adjusted to $26.00^{\circ} \mathrm{C}$ by means of the calorimeter heater
The calorimetric temperature observations were made at 2 -min intervals during a 20 -min "fore" rating period, at 1-min observations during a 60-min "reaction" period, and at 2 -min intervals during a 20-min "after" rating period. Diborane was passed slowly into the hydrolysis vessel at the start of the reaction period. After about $30 \mathrm{~min}$ the diborane cylinder was closed and the vessel was flushed with helium for about $30 \mathrm{~min}$.

The water vaporized from the hydrolysis vessel during the reaction period by the helium and hydrogen gases was collected in a weighed absorption tube containing magnesium perchlorate and phosphorus pentoxide. A correction was applied to the observed temperature rise for the heat of vaporization of this quantity of water. The hydrogen that was evolved in the hydrolysis passed through the first absorption tube, was burned to water in a copper-oxide furnace heated to $600^{\circ} \mathrm{C}$, and was collected in a second absorption tube. The quantity of reaction was determined from this mass of water. The temperatures of the diborane and helium. gases which entered the system during the reaction period were observed at 1-min intervals. The total quantity of helium was calculated from the mass of water in the first absorption tube on the assumption that the exit gases were saturated with water vapor at the mean temperature of the calorimeter. Only an approximate value for the quantity of helium was necessary in order to evaluate the correction for the gas heat capacity.

The electrical calibration experiments were carried out in the same manner except the diborane was omitted and a carefully measured quantity of electrical energy was introduced through the calorimeter heater. Measurements of the current through the heater and the potential drop across the heater were made on alternate minutes during the heating period. In a few of the calibration experiments the helium was omitted in order to test for systematic errors in the vaporization correction and to show whether or not the stirring caused by the bubbling of the helium through the water was necessary to obtain thermal equilibrium at the end of the experiment. Although no systematic errors were discovered it was found that a considerably longer period of time was required to obtain thermal equilibrium. when the helium was omitted.

At the end of each reaction experiment the pressures in the bubblers were equalized by opening the vent to prevent transfer of solution. The concentrations of boric acid in the bubblers were determined by titration with standard alkali in the presence of mannitol. Traces of crystalline boric acid, usually found in the connection between the bubblers, were washed out and the quantity determined in a separate titration. Agreement within the limits of the accuracy of titration was obtained between the stoichiometric amounts of boric acid and hydrogen. However, the amount of hydrogen oxidized to water was used as the measure of the quantity of reaction because this determination was more precise than the boric acid titration. 


\section{Results and Calculations}

The quantity of reaction was determined from the mass of hydrogen (as water) produced. This quantity of reaction was associated with a release of $q$ joules of energy given by the relationship

$$
(\Delta R c)\left(E_{s}\right)=q
$$

where $\Delta R c$ is the corrected temperature rise in ohms [15] and $E_{s}$ is the energy equivalent of the calorimetric system expressed in joules per ohm. The value $q$, when corrected for the heat of vaporization of water $q_{\text {(vap) }}$, the heat of dilution of the solutions to an arbitrary standard concentration $q_{(\mathrm{d} 11)}$, the heat of solution of the crystalline boric acid $q_{\text {(so In) }}$, and the heat capacities of the gases involved $q_{g}$ yields $q_{c}$, the corrected quantity of heat for $m$ moles of reaction under standard conditions. The heat of reaction is the ratio of $q_{c}$ to $m$ or

$$
\Delta H=q_{c} / m \text { joules } / \text { mole. }
$$

To convert to the conventional thermochemical calorie, the following relationship was used: 1 cal $=4.1840 \mathrm{j}$.

Two sets of data were taken using two slightly different calorimetric systems and two separate samples of diborane. The results of the electrical energy calibration experiments are given in table 1. The results for the diborane reaction experiments are given in table 2 . The final value for the heat of reaction was obtained as the mean of the experimental values and the uncertainty assigned was taken as twice the standard deviation of the experimental values combined with reasonable estimates of all known sources of error.

The value for the correction for the heat of dilution of boric acid was taken from the data of Davis, Mason, and Stegeman [16]. The value used for the correction for the heat of solution of boric acid was taken as $5.18 \mathrm{kcal} /$ mole $[9,17,18,19,20]$. The value

TABLE 1. Results of the electrical calibration experiments

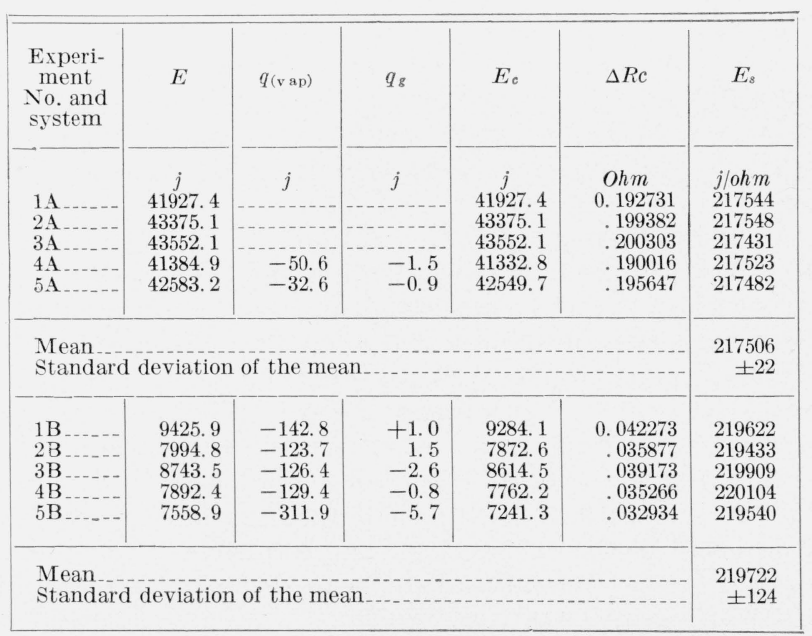

\begin{tabular}{|c|c|c|c|c|c|c|c|c|}
\hline $\begin{array}{l}\text { Experi- } \\
\text { ment } \\
\text { No. and } \\
\text { system }\end{array}$ & $\Delta R c$ & $q$ & $q(\mathrm{v} \mathrm{ap})$ & $q(\mathrm{di}])$ & $q_{(\text {soln })}$ & $q_{g}$ & $\mathrm{~B}_{2} \mathrm{H}_{6}$ & $\begin{array}{c}-\Delta \mathrm{H} \\
\left(25^{\circ} \mathrm{C}\right)\end{array}$ \\
\hline $\begin{array}{l}1 \mathrm{~A} \\
2 \mathrm{~A} \\
3 \mathrm{~A} \\
4 \mathrm{~B} \\
5 \mathrm{~B}\end{array}$ & $\begin{array}{c}\text { Ohm } \\
0.029524 \\
.007319 \\
.034260 \\
.034767 \\
.042940\end{array}$ & $\begin{array}{c}j \\
6421.6 \\
1591.9 \\
7451.8 \\
7639.1 \\
9434.9\end{array}$ & \begin{tabular}{r|r}
\multicolumn{1}{c|}{$j$} \\
195.7 \\
84.0 \\
208.5 \\
193.3 \\
191.9
\end{tabular} & $\begin{array}{c}j \\
-0.3 \\
+0.1 \\
-0.4 \\
-0.9 \\
-1.5\end{array}$ & $\begin{array}{c}j \\
-6.1 \\
-4.8 \\
-24.0 \\
-18.3 \\
-18.5\end{array}$ & $\begin{array}{c}j \\
-4.5 \\
-2.5 \\
-6.7 \\
-1.4 \\
-3.2\end{array}$ & $\begin{array}{c}\text { Moles } \\
0.014154 \\
.003561 \\
.016295 \\
.016890 \\
.020625\end{array}$ & $\begin{array}{r}k j / \text { mole } \\
466.75 \\
468.60 \\
468.19 \\
462.51 \\
465.63\end{array}$ \\
\hline \multicolumn{8}{|c|}{$\begin{array}{l}\text { Mean } \\
\text { Standard deviation of the mean }\end{array}$} & $\begin{array}{l}466.34 \\
\pm 1.10\end{array}$ \\
\hline
\end{tabular}

TABLE 2. Kesults of the diborane reaction experiments

used for the heat of vaporization of water was 10.514 $\mathrm{kcal} / \mathrm{mole}[21]$.

The data yield the following value for the heat of reaction of diborane with water:

$$
\begin{gathered}
\mathrm{B}_{2} \mathrm{H}_{6(\mathrm{~g}, 1 \text { atm })}+6 \mathrm{H}_{2} \mathrm{O}_{(1 \mathrm{iq})}+\left[2,000 \mathrm{H}_{2} \mathrm{O}\right]_{(1 \mathrm{lq})} \\
=2\left[\mathrm{H}_{3} \mathrm{BO}_{3}+1,000 \mathrm{H}_{2} \mathrm{O}\right]_{(\mathrm{soln})}+6 \mathrm{H}_{2(\mathrm{~g}, 1 \mathrm{~atm})} \\
\Delta \mathrm{H}_{298.15}=-466.34 \pm 2.26 \mathrm{kj} / \mathrm{mole} \\
=-111.46 \pm 0.54 \mathrm{kcal} / \mathrm{mole}
\end{gathered}
$$

The reference state of 1 mole of boric acid in 1,000 moles of water was selected instead of infinite dilution because of lack of data on heats of dilution in the very dilute range where ionization energies may become important.

The heat of formation of boric oxide can be calculated by combining the heat of reaction for eq (2) with the heat of formation of diborane

$$
\begin{gathered}
2 \mathrm{~B}_{(\text {amorph })}+3 \mathrm{H}_{2(\mathrm{~g})}=\mathrm{B}_{2} \mathrm{H}_{6(\mathrm{~g})} \\
\Delta \mathrm{Hf}_{298.15}=6.73 \pm 0.52 \mathrm{kcal} / \mathrm{mole}^{2} \quad[22],
\end{gathered}
$$

and with the following values taken from the available literature:

$$
\begin{aligned}
& \mathrm{H}_{2(\mathrm{~g})}+1 / 2 \mathrm{O}_{2(\mathrm{~g})}=\mathrm{H}_{2} \mathrm{O}_{(1 \mathrm{iq})} \\
& \Delta \mathrm{Hf}^{\circ}{ }_{298.15}=-68.317 \pm 0.007 \mathrm{kcal} / \mathrm{mole} \quad[21] \text {, } \\
& \mathrm{B}_{2} \mathrm{O}_{3(\text { amorph })}+3 \mathrm{H}_{2} \mathrm{O}_{(1 \text { iq })}+\left[2,000 \mathrm{H}_{2} \mathrm{O}\right]_{(\text {iq })} \\
& =2\left[\mathrm{H}_{3} \mathrm{BO}_{3}+1,000 \mathrm{H}_{2} \mathrm{O}\right]_{(\mathrm{soln})} \\
& \Delta \mathrm{H}_{298.15}=-7.90 \pm 0.03 \mathrm{kcal} / \mathrm{mole}[9,17,18,19] \text {, } \\
& \mathrm{B}_{2} \mathrm{O}_{3(c)}=\mathrm{B}_{2} \mathrm{O}_{3 \text { (amorph) }} \\
& \Delta \mathrm{H}_{298.15}=4.36 \pm 0.02 \mathrm{kcal} / \mathrm{mole} \quad[23] \text {, } \\
& \mathrm{B}_{(c)}=\mathrm{B}_{(\text {amorph })} \\
& \Delta \mathrm{H}_{298.15}=0.4 \pm 0.1 \mathrm{kcal} / \mathrm{mole}[21] .
\end{aligned}
$$

The following heats of formation of boric oxide are obtained from these values:

$$
\begin{aligned}
& 2 \mathrm{~B}_{\text {(amorph) }}+3 / 2 \mathrm{O}_{2(\mathrm{~g})}=\mathrm{B}_{2} \mathrm{O}_{3 \text { (amorph) }} \\
& \Delta \mathrm{Hf}_{298.15}=-1262.65 \pm 3.14 \mathrm{kj} / \mathrm{mole} \\
& =-301.78 \pm 0.75 \mathrm{kcal} / \mathrm{mole} \text {, } \\
& 2 \mathrm{~B}_{\text {(amorph) }}+3 / 2 \mathrm{O}_{2(\mathrm{~g})}=\mathrm{B}_{2} \mathrm{O}_{3(c)} \\
& \Delta \mathrm{Hf}_{298.15}=-1280.89 \pm 3.10 \mathrm{kj} / \mathrm{mole} \\
& =-306.14 \pm 0.74 \mathrm{kcal} / \mathrm{mole} \text {, }
\end{aligned}
$$




$$
\begin{gathered}
2 \mathrm{~B}_{(c)}+3 / 2 \mathrm{O}_{2(\mathrm{~g})}=\mathrm{B}_{2} \mathrm{O}_{3(\text { amorph })} \\
\begin{aligned}
\Delta \mathrm{Hf}_{298.15} & =-1259.30 \pm 3.14 \mathrm{kj} / \mathrm{mole} \\
& =-300.98 \pm 0.75 \mathrm{kcal} / \mathrm{mole} \\
& \\
& \\
\Delta \mathrm{Hf}^{\circ}{ }_{298.15} & =-1277.54 \pm 3.14 \mathrm{kj} / \mathrm{mole} \\
& =-305.34 \pm 0.75 \mathrm{kcal} / \mathrm{mole} .
\end{aligned}
\end{gathered}
$$

\section{Discussion}

This determination of the heat of formation of boric oxide has several distinct advantages over the regular bomb combustion procedure. With this procedure there is no uncertainty regarding the nature and state of the reaction products. When boron is burned in an oxygen bomb it is necessary to employ some auxiliary substance in order to obtain a reasonable quantity of reaction. In order for this auxiliary material to be effective it must prevent the molten boric oxide from covering the remainder of the boron which would terminate the reaction and leave an insoluble residue. When the auxiliary substance contains hydrogen the water formed in the combustion will react with the boric oxide to form boric acid. It then becomes necessary to estimate the amounts of boric oxide and boric acid present in the bomb after the combustion as well as the degree of solution of boric acid. These cannot be accurately determined from the theoretical quantity of water produced since a considerable portion condenses on the walls and head of the bomb. When a material containing no hydrogen is employed there is the further possibility that some of the boron alloys with the substance used; this portion then fails to burn.

The accuracy of the method described in this paper is limited only by the combined uncertainties in the measurements, since there can be little doubt as to the nature and state of the reaction products.

\section{References}

[1] W. A. Roth and E. Börger, Ber. [B] 70, 48 (1937).

[2] W. A. Roth, Z. Naturforsch 1, 574 (1946).

[3] J. A. Robertson, Thesis, Cornell University (1944).

[4] B. J. Todd and R. R. Miller, J. Am. Chem. Soc. 68, 530 (1946).

[5] W. Eggersgluess, A. G. Monroe, snd W. G. Parker, Trans. Faraday Soc. 45, 661 (1949)

[6] C. C. Nathan, Thesis (University of Pittsburgh, 1948).

[7] F. R. Bichowsky and F. D. Rossini, The thermochemistry of the chemical substances (Reinhold Publishing Corp., New York, N. Y., 1936).

[8] E. H. Winslow and H. A. Liebhafsky, J. Am. Chem. Soc. 64, 2725 (1942).

[9] W. A. Roth, E. Börger, and A. Bertram, Ber. [B] $\mathbf{7 0 ,}$ 971 (1937).

[10] E. M. Carr, J. T. Clarke, and H. L. Johnston, J. Am. Chem. Soc. \%1, 740 (1929).

[11] H. C. Dickinson, Bul. BS 11, 189 (1914) S230.

[12] N. S. Osborne, H. F. Stimson, and D. C. Ginnings, J. Resesrch NBS 23, 197 (1939) RP1228.

[13] E. J. Prosen, F. W. Maron, and F. D. Rossini, J. Research NBS 46, 106 (1951) RP2181.

[14] E. J. Prosen and F. D. Rossini, J. Research NBS 33, 255 (1944) RP1607.

[15] F. D. Rossini, Experimental thermochemistry, p. 136 (Interscience Publishers, Inc., New York, N. Y., 1956).

[16] W. D. Davis, L. S. Mason, and G. Stegeman, J. Am. Chem. Soc. 71,2775 (1949).

[17] E. R. Van Artsdalen and K. P. Anderson, J. Am. Chem. Soc. $\mathbf{7 3}, 579$ (1951).

[18] J. Smisko and L. S. Mason, J. Am. Chem. Soc. $\boldsymbol{7 2}$, 3629 (1950).

[19] M. von Stackelberg, F. Quatrum, and J. Dressel, Z. Elektrochem. 43, 14 (1937).

[20] C. Katz, Thesis (Cornell University, 1949).

[21] F. D. Rossini, D. D. Wagman, W. H. Evans, S. Levine, and I. Jaffe, Selected values of chemical thermodynamic properties, NBS Circ. 500, (U. S. Government Printing Office, Washington 25, D. C., 1952).

[22] E. J. Prosen, W. H. Johnson, and F. Y. Pergiel, J. Research NBS, 61, 247 (1958) RP2901.

[23] J. C. Southard, J. Am. Chem. Soc. 63, 3174 (1941).

Washington, August 19, 1958. 